GLOBAL WATER PATHOGEN PROJECT

PART FIVE. CASE STUDIES

\title{
HEALTH RISK OF BIOGAS EFFLUENT EXPOSURE AND HANDLING IN VIETNAM
}

\author{
Hung Nguyen-Viet \\ International Livestock Research Institute \\ Center for Public Health and Ecosystem Research - Hanoi University of Public Health \\ Hanoi, Vietnam

\section{Le Thi Thu} \\ Center for Public Health and Ecosystem Research - Hanoi University of Public Health \\ Hanoi, Vietnam

\section{Luu Quoc Toan} \\ Hanoi School of Public Health Vietnam \\ Hanoi, Vietnam

\section{Phuc Pham-Duc} \\ Center for Public Health and Ecosystem Research - Hanoi University of Public Health \\ Hanoi, Vietnam
}




\section{Copyright:}

\section{cc) (1) (2) \\ BY SA}

This publication is available in Open Access under the Attribution-ShareAlike 3.0 IGO (CC-BY-SA 3.0 IGO) license (http://creativecommons.org/licenses/by-sa/3.0/igo). By using the content of this publication, the users accept to be bound by the terms of use of the UNESCO Open Access Repository (http://www.unesco.org/openaccess/terms-use-ccbysa-en).

\section{Disclaimer:}

The designations employed and the presentation of material throughout this publication do not imply the expression of any opinion whatsoever on the part of UNESCO concerning the legal status of any country, territory, city or area or of its authorities, or concerning the delimitation of its frontiers or boundaries. The ideas and opinions expressed in this publication are those of the authors; they are not necessarily those of UNESCO and do not commit the Organization.

\section{Citation:}

Nguyen-Viet, H., Thu, L.T., Toan, L.Q. and Pham-Duc, P. (2019). Health risk of biogas effluent exposure and handling in Vietnam. In: J.B. Rose and B. Jiménez-Cisneros, (eds) Water and Sanitation for the 21st Century: Health and Microbiological Aspects of Excreta and Wastewater Management (Global Water Pathogen Project). (S. Petterson and G. Medema (eds) Part 5 Case Studies), Michigan State University, E. Lansing, MI, UNESCO. https://doi.org/10.14321/waterpathogens.69

Acknowledgements: K.R.L. Young, Project Design editor; Website Design: Agroknow (http://www.agroknow.com)

Last published: March 21, 2019 


\section{Summary}

\section{Highlights}

- The study provides a framework to estimate the health risk of farmers exposed to biogas effluent.

- The study addresses the SDG 6.3: to contribute to inform water recycling and reuse.
- Exposure to biogas effluent represents an important health risk.

- Risk mitigation should focus on exposure reduction including raising farmer awareness and use of personal protective equipment

- Treatment of wastewater at the source to improve water quality is needed for long term intervention

\section{Graphical abstract}
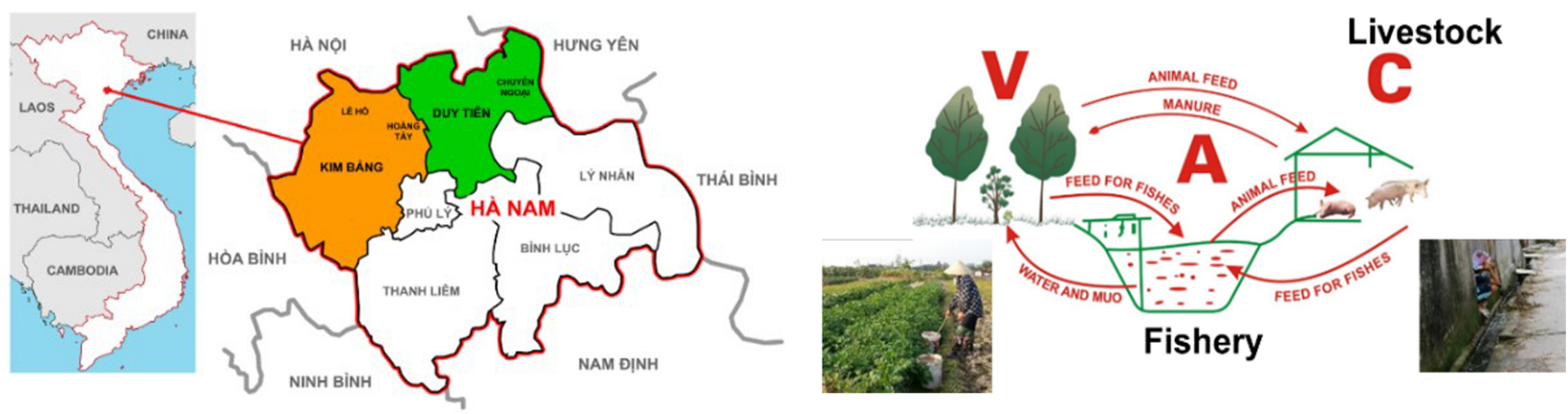

(Image reproduced with permission of CAB International 2015. In Chapter 9: Integrated Human and Animal Sanitation One Health: The Theory and Practice of Integrated Health Approaches.)

\section{Summary}

\section{Risk Management Objective}

The objective of this case study was to assess the diarrhea risks caused by exposure to pathogens in biogas wastewater. We aimed to assess the risk, and to recommend how farmers can reduce the risk when using biogas effluent and promote safe use of effluent. The overall management objective was to develop an integrated strategy for pathogen management and public health control in the agricultural setting.

\section{Location and Setting}

In Vietnam, the reuse of wastewater for agriculture is popular. Due to poor treatment of wastewater before use, health risks posed by reuse activities might be important. Biogas has been used widely to treat animal manures and biogas effluent is reused for irrigation of crops and trees. 


\section{Description of the System}

The study was carried out in three communities of 24,400 people for 6,200 household in Ha Nam Province. The economic basis of these three communities relies on both livestock and crops. The total swine population in three communities was around 17,600 and almost all of them are raised at small household scale. Household biogas is used to treat manure and human excreta. While the treatment technology looks promising and clean, the treatment quality and health risk posed by biogas effluent are questionable.

\section{Outcome and Recommendations}

- Pathogens (E. coli, G. lamblia, and C. parvum) remained at high concentrations in the biogas wastewater. The single and annual risks of diarrhea caused by these pathogens in the exposed activities were relatively high.

- Further actions to improve the biogas effluent quality are required to reduce health risk due to the exposure to biogas wastewater.

- Enhance the awareness of people when handling biogas wastewater, and promote practices of using personal protective measures.

- Results in this study could be taken into consideration to understand the health risks associated with exposure to biogas wastewater through different activities in other areas of Vietnam as well as in other developing countries with a similar context of applying biogas plants.

\section{Introduction}

The global increase in demand for livestock products has led to many concerns about the associated negative impacts of livestock rearing on the environment and on human health. In Vietnam, especially, the management of animal waste has become a considerable challenge due to the rapid increase in swine production. A common method to treat animal waste in Vietnam is anaerobic digestion, also called biogas technology. This is a microbiological process whereby organic matter is decomposed in the absence of oxygen. Animal manure as well as human faeces can be used as feedstock. The outputs of anaerobic digestion are biogas (a mix of methane and $\mathrm{CO}_{2}$ ) and a digestate wastewater, which is the digested slurry existing the biogas reactor. The efficiency of the biogas reactor in inactivating pathogens will depend upon the temperature and the residence time, which in turn will depends upon the efficiency of the hydraulics within the reactor.

Biogas plants in Vietnam have often been installed by farmers individually, and mostly at household scale without much technical support or advice. This frequently leads to biogas plants which are not properly designed, constructed, operated or maintained. This limits the efficiency of microbial removal and thereby affects biogas production.

Ha Nam is a province in the North of Vietnam where there is frequent use of biogas plants with farming households raising pigs. Many of these farmers use this effluent for irrigation of vegetables, crops and fruit trees, or then discharge it to drains. In addition, local people rarely us protective measures when handling the biogas wastewater to prevent exposure.

The risk associated with handling biogas effluent is not well known. The aim of this study was to quantitatively assess the diarrhea risk associated with exposure to biogas wastewater, that could occur while undertaking a range of common activities. The results were intended to provide a better assessment of health risk, assess safety and identify the need for further interventions.

\section{Problem Formulation}

The purpose of the QMRA was to assess the illness risk associated with exposure to biogas effluent while undertaking common activities. The scope of the QMRA was defined by:

- Hazard identification:Three enteric pathogens that can be transmitted from animals to humans were used as reference pathogens for the investigation: E. coli 0157:H7, G. lamblia and $C$. parvum. Previous studies carried out in Vietnam showed high load of these pathogens in biogas effluent (Huong et al. 2014; Kobayashi et al., 2003) and wastewater (Phuc, 2012) and reported high prevalence of diarrhea in communities (Phuc, 2012; Trang et al., 2007).

Exposure pathways: Four scenarios of biogas effluent exposure were considered: (1) Irrigating crops (2) irrigating fruit trees (3) irrigating vegetables, and (4) unblocking the open drains connected to the effluent tanks. In each case, exposure was assumed to occur due to accidental ingestion of wastewater by splashing directly into the mouth or indirectly on hands and then to the mouth.

Health outcome:The annual risk of illness from each of the three reference pathogens was assessed. A stochastic assessment was selected to quantify the variability in quantified risk.

\section{Exposure Assessment}

a) Source: From three communities, 15 households with biogas plants were randomly selected. At each household, two sampling points were identified: the first one at the effluent tank of the biogas plant and the second at the open household drain into which biogas effluent, wastewater and other runoff flow (Figla). 


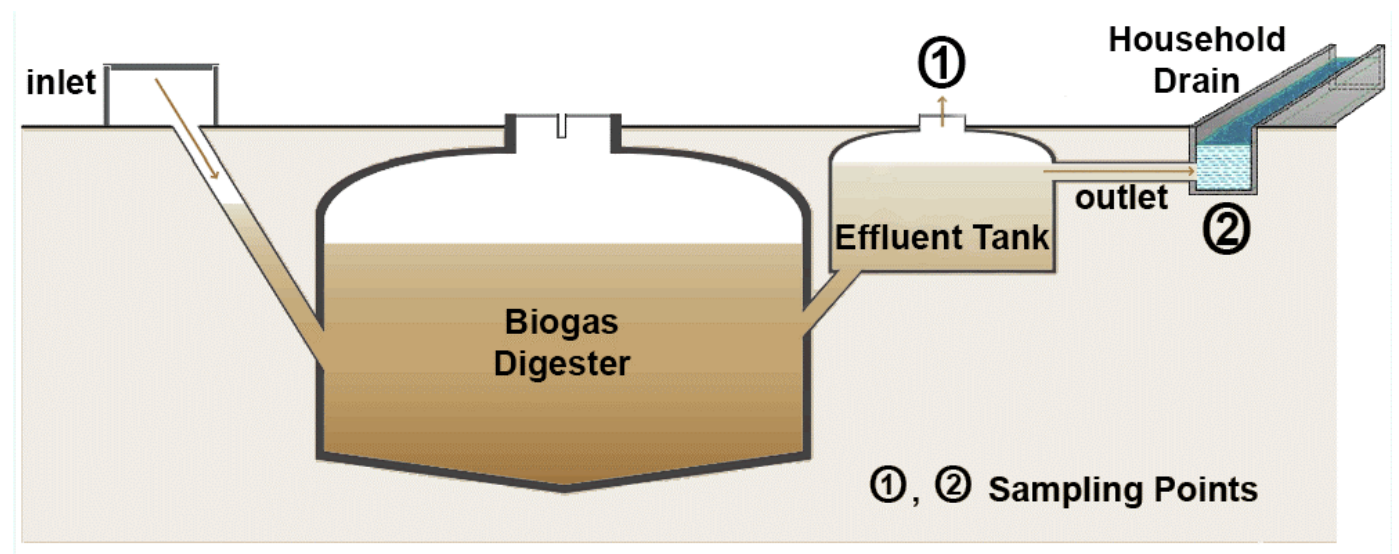

Figure 1 a) Scheme of a biogas plant and the two sampling points [Source adapted from Tilley et al., 2014)] (Image reproduced with permission of RightsLink / Springer Nature).

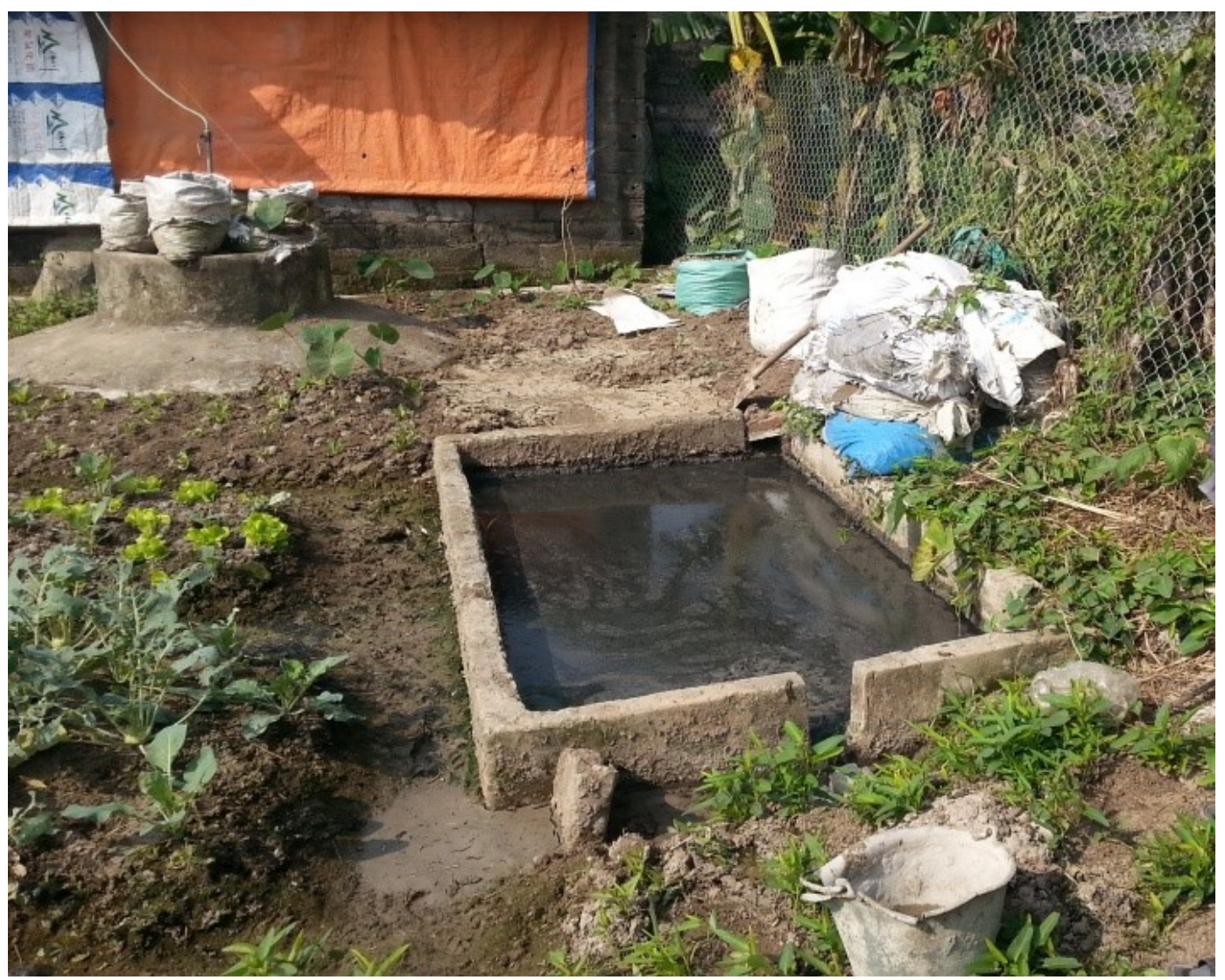

Figure 1 b) An open effluent tank of biogas plant in Hoang Tay, Ha Nam Province, Vietnam, 2014. (Image reproduced with permission of RightsLink / Springer Nature). 


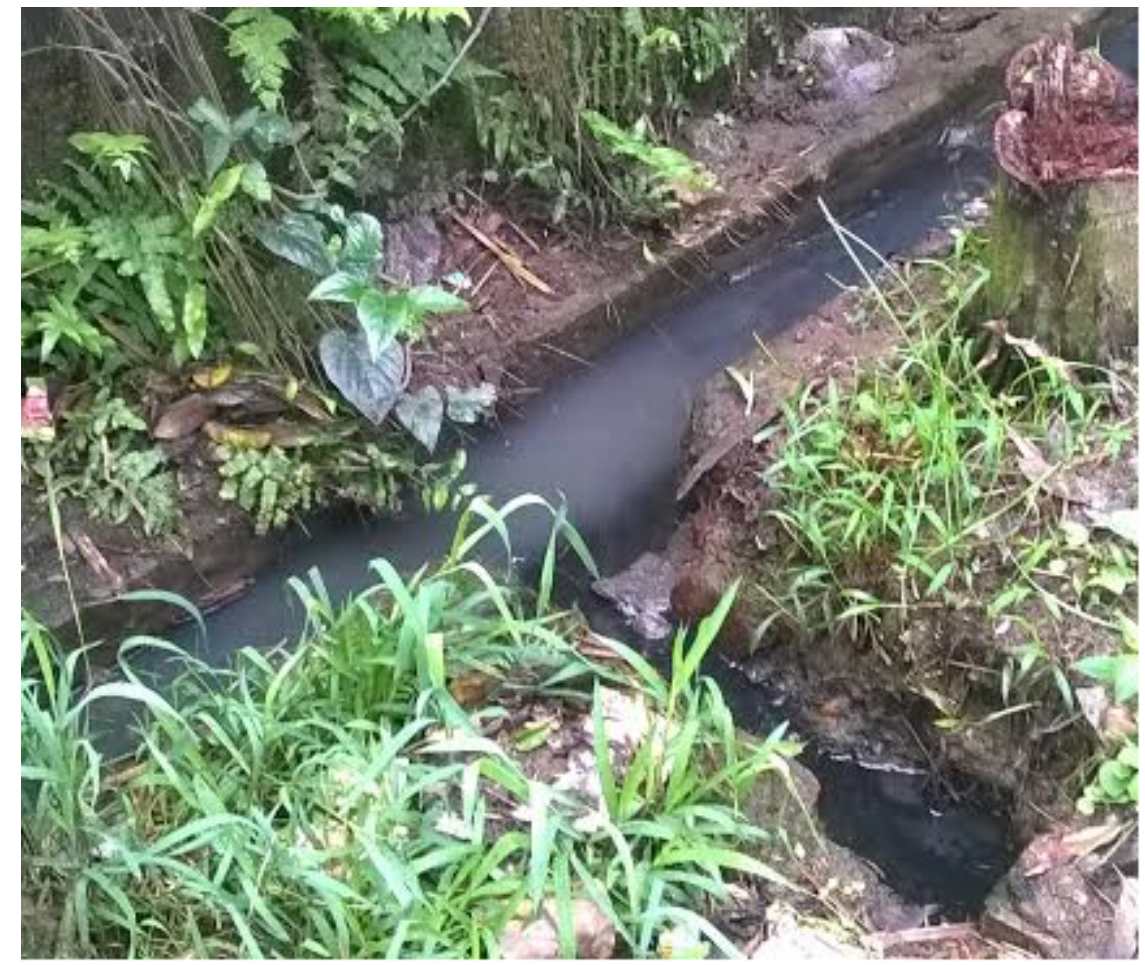

Figure 1 c) Open drain receiving biogas effluent in Hoang Tay, Ha Nam Province, Vietnam, 2014. (Image reproduced with permission of RightsLink / Springer Nature).

The effluent tank of the biogas plant is a point of exposure as that is where farmers collect effluent for irrigation of fields (see Fig 1b). The household open drain is also considered a potential point of exposure as this drain often needs to be unblocked by users (see Fig 1c). Three wastewater samples were collected at each sampling point. Thus, five rounds of sampling gave us a total of 150 wastewater samples collected from April to December 2014. Results are summarised in Table 1.

Table 1. Mean concentrations of pathogens at two exposure points from 15 households in three communes of Ha Nam Province, Vietnam, 2014. (Source: Le-Thi et al., 2017)

\begin{tabular}{|c|c|c|c|c|c|c|c|c|}
\hline \multirow[t]{2}{*}{ Sampling Points } & Pathogens & $\underset{\text { of }}{\text { Number }}$ & $\begin{array}{c}\text { Number } \\
\text { of } \\
\text { Positive }\end{array}$ & \multicolumn{5}{|c|}{ Concentrations } \\
\hline & & & & unit & Mean & SD* & Min & $\operatorname{Max}$ \\
\hline \multirow[t]{3}{*}{ Biogas Effluent in Effluent Tanks } & E. coli & 75 & $75(100)$ & $\mathrm{CFU} / 100 \mathrm{~mL}$ & $14.7 \mathrm{E}+05$ & $34.9 E+05$ & 320 & $200 E+05$ \\
\hline & G. lamblia & 75 & $33(44.0)$ & Cysts/100mL & 19 & 46 & 0 & 260 \\
\hline & C. parvum & 75 & $26(34.7)$ & Oocysts/100mL & 18 & 51 & 0 & 400 \\
\hline \multirow[t]{3}{*}{$\begin{array}{c}\text { Drains Connected to Effluent } \\
\text { Tanks } \\
\end{array}$} & E. coli & 75 & 75 (100) & CFU/100mL & $9.3 \mathrm{E}+05$ & $25.7 \mathrm{E}+05$ & 10 & $200 \mathrm{E}+05$ \\
\hline & G. lamblia & 75 & $18(24.0)$ & Cysts/100mL & 4 & 7 & 0 & 30 \\
\hline & C. parvum & 75 & $22(29.3)$ & Oocysts $/ 100 \mathrm{~mL}$ & 12 & 56 & 0 & 480 \\
\hline
\end{tabular}

*SD standard deviation 
b) Barriers/controls: No barriers were considered in the risk calculations, however use of personal protective equipment was investigated by survey,

c) Exposure: A survey was conducted in each of the three communities to assess the intensity and duration of exposure associated with each of the defined activities. From a total of 1500 households with biogas plants, 451 households were randomly selected. The survey recorded basic characteristics of biogas including their age, material used (animal or with human faeces) and residence time. The majority of respondents (84\%) indicated that their main occupation was working in agriculture. The frequency of exposure, ingestion dose of wastewater, and percentage of the population who participated in each exposure event are shown in Table 2. For the study, it was assumed that $1 \mathrm{~mL}$ of wastewater would be involuntarily ingested with each exposure event (Hoglund et al., 2002; Ottoson and Stenstrom, 2003).

Table 2. Dose assumptions, frequency of exposure and percentage of the exposure population in 3 communes of Ha Nam Province, Northern Vietnam, 2014 (Source: Le-Thi et al., 2017)

\begin{tabular}{|c|c|c|c|c|}
\hline Sampling Points & Activities & $\begin{array}{c}\text { Ingestion } \\
\text { Dose of } \\
\text { Wastewater }\end{array}$ & $\begin{array}{c}\text { Average } \\
\text { Frequency } \\
\text { (event/year) }\end{array}$ & $\begin{array}{c}\text { Percentage } \\
\text { of } \\
\text { Population } \\
\text { (\%) }\end{array}$ \\
\hline \multirow[t]{3}{*}{ Biogas Effluent in Effluent Tanks } & $\begin{array}{l}\text { Irrigating } \\
\text { vegetables }\end{array}$ & $1 \mathrm{~mL} /$ event $^{\mathrm{a}}$ & 48 & 26 \\
\hline & $\begin{array}{l}\text { Irrigating } \\
\text { crops }\end{array}$ & $1 \mathrm{~mL} /$ event & 32 & 28 \\
\hline & $\begin{array}{l}\text { Irrigating } \\
\text { fruit trees }\end{array}$ & $1 \mathrm{~mL} /$ event & 24 & 24 \\
\hline Drains Connected to Effluent Tanks & $\begin{array}{l}\text { Unblocking } \\
\text { drains }\end{array}$ & $1 \mathrm{~mL} /$ event $^{\mathrm{b}}$ & 53 & 30 \\
\hline
\end{tabular}

${ }^{a}$ Microbial risk assessment of source-separated during used in agriculture (Hoglund et al. 2002; Ottoson and Stenstrom 2003)

${ }^{\mathrm{b}}$ Fecal contamination of greywater and associated microbial risks (Hoglund et al., 2002; Ottoson and Stenstrom 2003)

\section{Health Effects Assessment}

The probability density functions used in the risk calculations for source and exposure are given in the original publication (link below)
Dose-response models, and illness probabilities from the published literature were selected for each of the three reference pathogens. These are summarised in Table 3. 
Table 3. Health effects assessment assumptions applied in the study

\begin{tabular}{|c|c|c|c|c|}
\hline Reference Pathogen & Dose-Response Model & Reference & $\begin{array}{c}\text { Probability of Illness Given } \\
\text { Infection }\end{array}$ & Reference \\
\hline E. coli $\mathrm{O} 157: \mathrm{H7}$ & $\begin{array}{cc}\text { Beta-Poisson } & \text { ID50:214.94; } \\
\text { approximation } & a=0.373\end{array}$ & $\begin{array}{l}\text { Teunis et } \\
\text { al. } 2008\end{array}$ & 0.25 & $\begin{array}{l}\text { Howard et } \\
\text { al. } 2006\end{array}$ \\
\hline G. lamblia & Exponential & $\begin{array}{c}\text { Haas and } \\
\text { Eisenberg, } \\
2001\end{array}$ & 0.67 & $\begin{array}{c}\text { Rose et al. } \\
1991\end{array}$ \\
\hline C. parvum & Exponential & $\begin{array}{c}\text { Haas and } \\
\text { Eisenberg, } \\
2001\end{array}$ & 0.7 & WHO,2006 \\
\hline
\end{tabular}

\section{Risk Characterization}

The annual risk of diarrhea, it was assumed that exposure to biogas wastwater through the selected activities in this study were the only cause of diarrhea. The annual risks of diarrhea caused by the chosen pathogens are presented in
Figure 2. The E. coli, G. lamblia and C. parvum remained at high concentrations in the biogas wastewater. The single and annual risks of diarrhea caused by these pathogens in the exposed activities were relatively high.

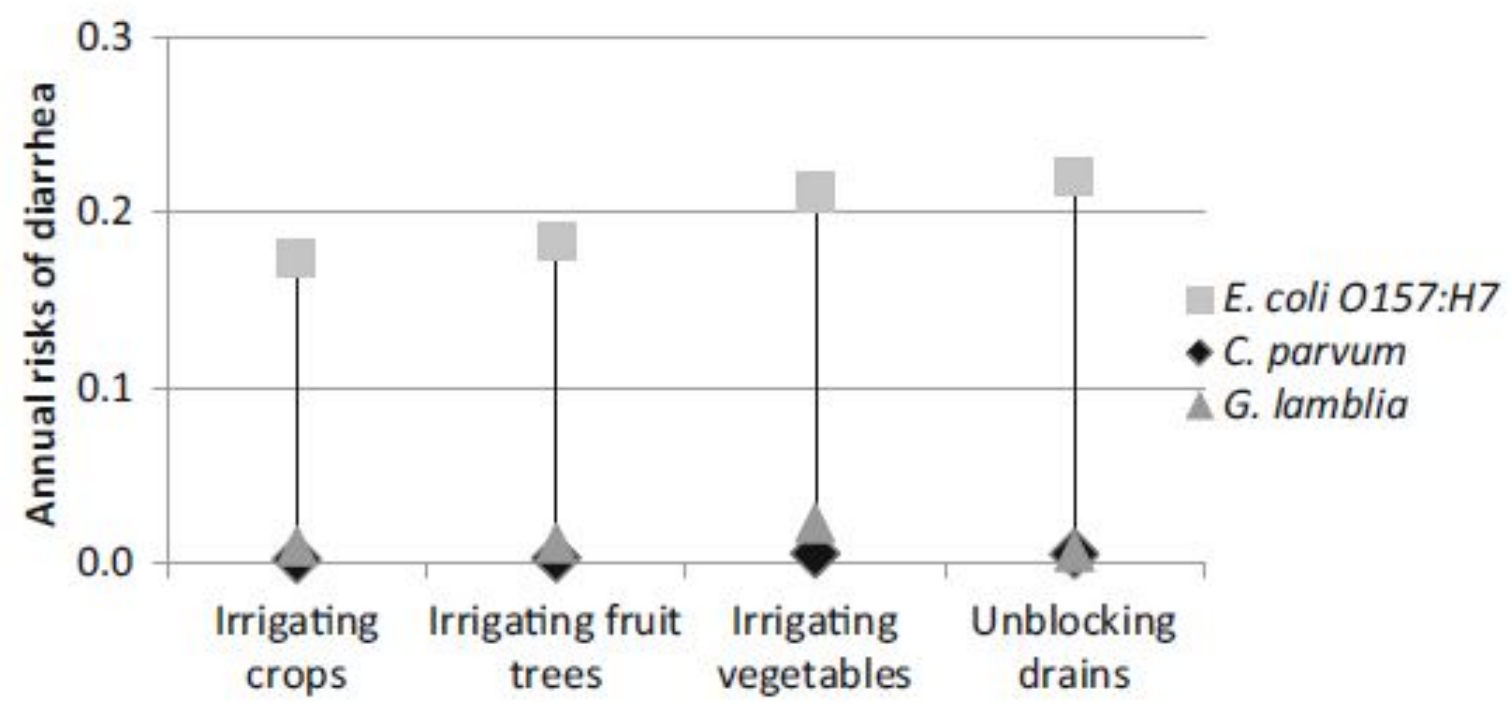

Figure 2. Annual risks of diarrhea in the different activities estimated by 10,000 trial Monte Carlo simulations in Vietnam, 2014 (Source: Le-Thi et al., 2017)

\section{Risk Management}

The high risks calculated in this study suggest that further actions to improve biogas effluent quality are required to reduce health risk. The study provides evidences to enhance the awareness of people when handling biogas wastewater, and hence promoting practices of using personal protective measures including wearing gloves, wearing face masks, wearing boots and washing hands with soap after work.

\section{Evaluation of the QMRA}

The QMRA provided a way to interpret the significance of the measured concentrations of pathogens in the biogas wastewater. The investigation of how biogas wastewater was being used in the community, together with potential exposure scenarios, allowed for the local context to be considered. In addition, the current use (or non-use) or protective equipment provided context for the efficacy of existing risk management options. The combination of 
environmental microbiology, analysis of local behaviours and quantified in terms of diarrheal risks, provides a powerful platform to advocate for improved safety, and community understanding of the risks associated with the biogas wastewater.

Read the full article at: https://link.springer.com/article/10.1007/s00038-016-0917- 


\section{References}

Höglund, C., Stenström, T.A. and Ashbolt, N. (2002). Microbial risk assessment of source-separated urine used in agriculture. Waste Management and Research. 20, pp. 150-161.

Haas, C.N. and Eisenberg, J.N.S. (2001). Risk Assessment. Water Quality: Guidelines, Standards and Health. (Fewtrell, L. and Bartram, J., ed.). IWA Publishing. London. pp. 161-183.

Howard, G., Pedley, S. and Tibatemwa, S. (2006). Quantitative microbial risk assessment to estimate health risks attributable to water supply: can the technique be applied in developing countries with limited data?. Journal of Water and Health. 4, pp. 49-65.

Huong, L.Q., Madsen, H., Ngoc, P.T. and Dalsgaard, A. (2014). Hygienic aspects of livestock manure management and biogas systems operated by small-scale pig farmers in Vietnam. Science of the Total Environment. 470, pp. 53-57.

Kobayashi, H., Khai, L.T.L., Phan, T.T., Yamasaki, S. and Taniguchi, T. (2003). Prevalence of pathogenic Escherichia coli in a swine breeding environment in Can Tho province, Vietnam. Japan Agricultural Research Quarterly: JARQ. 37, pp. 59-63.

Le-Thi, T., Pham-Duc, P., Zurbrügg, C., Luu-Quoc, T., Nguyen-Mai, H., Vu-Van, T. et al. (2017). Diarrhea risks by exposure to livestock waste in Vietnam using quantitative microbial risk assessment. International journal of public health. 62(1), pp. 83-91.

Ottoson, J. and Stenström, T.A. (2003). Faecal contamination of greywater and associated microbial risks. Water Research. 37, pp. 645-655.

Pham-Duc, P. (2012). Wastewater and excreta use in agriculture in northern Vietnam: health risks and environmental impacts.

Rose, J.B., Haas, C.N. and Regli, S. (1991). Risk assessment and control of waterborne giardiasis. American Journal of Public Health. 81, pp. 709-713.

Teunis, P.F.M., Ogden, I.D. and Strachan, N.J.C. (2008). Hierarchical dose response of E. coli O157: H7 from human outbreaks incorporating heterogeneity in exposure. Epidemiology and Infection. 136, pp. 761-770.

Tilley, E. (2014). Compendium of sanitation systems and technologies. Eawag.

Trang, D.T., Hien, B.T.T., Mølbak, K., Cam, P.D. and Dalsgaard, A. (2007). Epidemiology and aetiology of diarrhoeal diseases in adults engaged in wastewater-fed agriculture and aquaculture in Hanoi, Vietnam. Tropical Medicine and International Health. 12, pp. 23-33.

WHO (2006). Guidelines for Drinking Water Quality: Incorporating first addendum. 1, Recommendations - 3rd Edition, World Health Organization. Geneva. 